\title{
Steering the future. The emergence of "Western" futures research and its production of expertise, 1950s to early 1970s
}

\author{
Elke Seefried
}

Received: 15 September 2013 / Accepted: 17 October 2013 /Published online: 4 December 2013

(C) The Author(s) 2013. This article is published with open access at Springerlink.com

\begin{abstract}
This article deals with the emergence of Futures Research after 1945 and its production of future expertise. The field of futures research (or futures studies/futurology) was conceptualised in a process of circulating knowledge in Western Europe and the USA during the 1950s and 1960s. These approaches to thinking about, forecasting and planning the future drew their arsenal of new methods largely from the field of cybernetics (such as Systems Analysis). What is more, futures research produced expertise for policy development and strategic planning. As a result of the dynamic changes in science and technology and the breakthrough of Keynesianism, the 1960s symbolized the high time of political planning in Western Europe and the USA. The paper aims to analyse the forms and character of future expertise utilized in government and administration during the 1960s. It will focus on West German futures research and its advisory role for the Federal Government but will also take transnational transfers of knowledge and comparative aspects into account. The paper will show that major strands of futures research of the 1960s were explicitly confident that they would be able to plan and control the future by using "modern" and rational methods. This led partly to a euphoria of steering. In the early 1970s, however, this confidence was shattered. One reason for this were dramatic problems in utilizing future expertise in government.
\end{abstract}

Keywords History of futures research/Future(s) studies/ Futurology/Zukunftsforschung $\cdot$ Cybernetics $\cdot$ Systems analysis · Federal Government - Scientific policy advice . Early warning system $\cdot$ Can-do mind-set

\footnotetext{
E. Seefried $(\bowtie)$

Institut für Zeitgeschichte München-Berlin, Leonrodstraße 46b, 80636 Munich, Germany

e-mail: seefried@ifz-muenchen.de
}

In 1967, Olaf Helmer of the RAND Corporation published an article on "Long range forecasting", which began as follows:

"The decade of the Sixties has brought with it an important change in the intellectual climate throughout many parts of the world, evidenced by a new attitude toward the future that has become apparent in public and private planning agencies as well as in the research community. The effect has been to extend customary planning horizons into a more distant future and to replace haphazard intuitive gambles, as a basis for planning, by sober and craftsmanlike analysis of the opportunities the future has to offer. [...] The future is no longer viewed as unique, unforeseeable, and inevitable; there are, instead, a multitude of possible futures, with associated probabilities that can be estimated and, to some extent, manipulated." [42 Helmer, p 1-2].

Very similarly, and influenced by circulating knowledge, the West German Centre Berlin for Futures Research (Zentrum Berlin für Zukunftsforschung) propagated in a founding paper in 1968: "One begins to realise that there is a wealth of possible futures and that these possibilities can be shaped in different ways". ${ }^{1}$

Evidently, the new meta-discipline of futures research was built on the assumption that a multitude of possible futures existed, which could be estimated, forecast and manipulated. Seen from this perspective, it seemed feasible to steer future developments. This aim had a somehow euphoric touch and was very close to aspirations propagated by actors in the political field. The West German Social Democratic Party

\footnotetext{
${ }^{1}$ First information broschure of the "Zentrum Berlin für Zukunftsforschung"(Centre Berlin for Futures Research), undated (1968), Bundesarchiv Koblenz, B 138, 1550
} 
(SPD), part of the "grand coalition", propagated in its "Perspectives" in early 1969:

"The status of science today allows us to look ahead. A form of politics oriented towards the future must be inspired by the will to prevent noticeable and undesirable developments, to tackle at an early stage noticeable and undesirable developments, but above all: to recognise, to promote and to initiate desirable developments." [93 Sozialdemokratische Partei Deutschlands, p 33].

The Social Democratic Party was more or less confident that science would possess the tools needed to systematically anticipate possible, probable and "willed" futures, thus providing the knowledge for future-oriented politics, for modernization and planning. Did futures research provide scientific policy advice? Which forms of knowledge were utilized in government and what were the effects of this future expertise? This article explores the "founding years" of modern futures research in Western industrialised countries emerging in the late 1950s and 1960s (I.). ${ }^{2}$ It furthermore sheds light on the forms of knowledge produced as well as the ways and extent to which this expertise was utilized for government and administration in the late 1960s and early 1970s (II.) This second chapter focuses on West German futures research but also takes transnational transfers of knowledge into account. Expertise is understood here as an informed, though not necessarily scientific, knowledge with a link to political decision-making and solving of relevant social problems [83 Saretzky]. It should be kept in mind here that scientific knowledge is never incorporated into the political process on a one-to-one basis, but that the communication channels, the flow and diffusion of knowledge between the experts, politics and administration are of epistemological interest [8 Ash; 36 Gieryn; 106 Weiss; 10 Beck \& Bonß; 80 Ronge; 104 Weingart 1983]. This is also true for the public sphere(s). As scientific knowledge is always inextricably linked with its cultural and social contexts, recent research focuses on the mutual influencing processes and interactions between science, politics and the public arena [23 Daston; 28 Felt; 86 Schirrmacher; 105 Weingart].

The article aims at showing that future thinking in the 1960 s was dominated by ideas of feasibility (Machbarkeitsdenken) and some sort of technological optimism, as most exponents of the futures field were confident that they would be able to plan and steer the future by using "modern" and rational methods. Driven by a can-do mind-set, this led partly to a euphoria of

\footnotetext{
$\overline{2}$ The history of "Western" futures research remained a desideratum of interdisciplinary and historical research until the early 2000s. For an inside, albeit fruitful, perspective, see 21 Cornish; 62 Kreibich, Canzler \& Baumeister; 94 Steinmüller, and 12 Bell. For recent studies see 87 Schmidt-Gernig; 88 Schmidt-Gernig; 7 Andersson; 89-91 Seefried.
}

steering. In the early 1970 s, however, this confidence was shattered. One reason for this were dramatic problems in utilizing future expertise in government and administration. Central strands of futures research in the 1970s developed a more pragmatic understanding of thinking about, forecasting and planning the future.

\section{The emergence of futures research in western industrialized countries in the 1950s and 1960s}

Of course, forecasting the future was nothing new in the $1950 \mathrm{~s}$ and can be traced back in history. In the 18th century, as the historian Reinhart Koselleck argued, the horizons of expectation were separated from the spaces of experience. Teleological interpretations and Christian expectations of salvation were superseded by notions of an open future and the belief in "worldly" progress. Prophecies were superseded by prognostics. This was crucial for modern temporal consciousness and self-consciousness, for social and political developments, as the "saddle period" (Sattelzeit) opened up the floor to plans and utopias [60 Koselleck]. In the industrial age people came to believe that the study of the natural and social world would help them make progress and "gain some kind of control over the passing of time". Rationality, science and technology seemed to allow control over nature and enable people to plan and steer the future [45 Hunt, p 25]. The intertwining of technological changes and thoughts about the future might be traced in any historical period [ 45 Hunt], but was especially noticeable in the decade from the late 1950 s to the late 1960s.

Hence, it was this time when "modern" futures research was conceptualised in the USA and Western Europe. Generally, futures research grew out of dynamic developments in science and technology in a Techno-Scientific Age. These developments were inextricably linked with the Second World War and the emerging Cold War. During the Second World War, the British Royal Navy and the US Office of Scientific Research and Development designed new techniques and tools of military planning by using mathematical knowledge labelled as Operations Research.$^{3}$ After 1945, in the shadow of the Manhattan Project and the emerging Cold War, the US government in particular relied on so-called Big Science which meant that governments funded large-scale projects managed by universities and research institutes, employing hundreds or thousands of scientists and technicians

\footnotetext{
${ }^{3}$ Carroll Wilson of OSRD defined Operations Research as "developing tactics for the most effective use of equipment and forces [and conducting] equipment analysis which is concerned with [...] obtaining maximum performance from equipment through improvement of installation, maintenance, calibration, and testing procedures". Quoted in 78 Rau, p 77; see further 58 Kirby, p 66-92; 31 Fortun \& Schweber; 75 Pircher.
} 
on an interdisciplinary basis [34 Galison \& Hevly; 67 Leslie]. These think tanks, such as the RAND Corporation, provided the methods and techniques for the military and strategic planning of US administrations [1 Abella; 5 Amadae; 20 Collins]. Methodologically, these new methods were based on the theoretical foundations of behaviourism, and they drew their arsenal mainly from two new theories developed in close proximity to the think tanks. These were, on the one hand, game theory as an approach to estimating strategic decisions in conflict situations [73 Neumann \& Morgenstern; 66 Leonard], and, on the other hand, cybernetics as the new meta-science of communication and control in animate and inanimate systems. Stating that biological, technological, and social systems behave quite similarly in that they are structured by transfers of information, cybernetics explored regulation and control mechanisms and information flows within complex systems and between the system and its environment. From a natural science point of view, cybernetics seemed to be a meta-approach to understanding how systems behave, how they "learn" by integrating new information and how they can be steered [107, 108 Wiener; 39 Hagner; 49 Heims; 92 Schmidt-Gernig]. At RAND, Systems Analysis was designed as a cybernetics-inspired science of strategy which laid the foundations for methods such as systems-based computer simulations, war gaming and a systematic analysis of experts' opinions on specific future developments (the socalled Delphi method) to forecast the future. ${ }^{4}$

However, the think tanks only provided the methods. Ideas to conceptualise futures research as a meta-discipline to think about, forecast and plan the future grew out of transatlantic circulations of knowledge. The central forum was the Congress for Cultural Freedom. Shaped by the mentalities of the Cold War, the Congress brought together intellectuals, scientists and politicians under the aegis of consensus liberalism. As such, the Congress promoted consensual democracy, liberal capitalism and anti-Marxism but also pleaded for planning and reform policy. The Congress was supported by the CIA and closely connected with the Ford Foundation which projected a philanthropic interest but in fact had also other, very much political aims. It sought to anchor a positive image of American culture in the West and in the so-called Third World, also linking European social sciences more closely with the American social sciences and modernization theory, which epitomized a "framework for objective social analysis

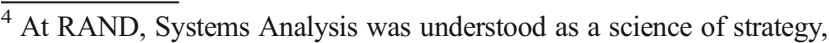
referring to the "complex problem of choice among alternative future systems, where the degrees of freedom and the uncertainties are large, where the difficulty lies as much in deciding what ought to be done as in how to do it": 98 The RAND Corporation, p. 27; cf pp 26-28; 20 Collins 2002, pp 170-173; 35 Ghamari-Tabrizi 2000, pp 171-2, 209-11; for "Delphi” 37 Gordon/Helmer.
}

and a powerful vehicle for social engineering" [63 Latham, $p$ 2; further 19 Coleman; 44 Hochgeschwender; 92 Seybold; 14 Berghahn pp 153-70, 183-31]. A key role in these networks played the French political scientist Bertrand de Jouvenel, who provided the theoretical reflection on thinking about the future. He was inspired by circulating knowledge of US intellectuals such as Daniel Bell who emerged as one of the intellectual "founders" of futures research in the USA by presiding over the US Commission on the Year 2000. ${ }^{5}$ Furthermore, emigrants acted as contact people such as Olaf Helmer who connected the epistemological foundations from the German school of logistical empiricism with methodology knowledge from RAND [79 Rescher]. Consequently, futures research institutions were set up in the 1960s, f.e. the "Institute for the Future" in the USA and the "Centre Berlin for Futures Research" in West Germany [70 McHale \& McHale].

All those researchers who conceptualised the scientific approaches to the future in the late 1950s and 1960s shared three characteristics. First, they perceived that the pace of technological, scientific and social change was accelerating. An exponential growth of scientific knowledge was noted in the fields of aerospace research, nuclear energy and data processing. Given the perception of acceleration, the knowledge of the past seemed to offer less and less that was useful for solving future problems. Thus, the acknowledgement of acceleration was bound up with a concern for how to control future developments [13 Berger; 25 de Jouvenel, p 23-4; 53 Jungk, p 9].

However, and this is the second characteristic, the growth of scientific knowledge also seemed to offer specific methods and new tools for researching and controlling rapid change in its complexity and in the medium to long term. This was, on the one hand, the computer by saving big data for simulating future developments [4 Agar], and, on the other hand, cybernetics. Cybernetics was hyped as the new meta-science, which promised to unify knowledge across the boundaries separating the natural from the social sciences and the humanities, and as a technique for analysing internal processes of systems by exploring feedback loops, thus enabling people to estimate and somehow steer the future development of whole systems [39 Hagner; 97 Tanner]. Hence, futures research was dominated by the confidence that science could forecast future developments of systems and future consequences of decisions and thus steer the future towards some sort of progress.

\footnotetext{
${ }^{5} 25$ De Jouvenel; see correspondence between Daniel Bell and de Jouvenel. Bibliothèque Nationale de France, NAF 28143, 294; Congress for Cultural Freedom, Minutes of the Second Meeting of the Planning Committee on Tradition and Social Changes- Social Progress, 8th Feb 1958, ibid, 34; Ford Foundation Archives, Grant File 61-41; 11 Bell; 7 Andersson, pp. 1417-8; 22 Dard, pp 327 ff
} 
This perception was bound up with the third, most important characteristic. All exponents of the futures field were driven by the conviction that many possible futures existed to think about and to be created. Bertrand de Jouvenel coined the term futuribles, combining "future" and "possible", around 1960 [25 de Jouvenel, p 35]. Hence, the plural of "futures" epitomized a central principle of all Western concepts of studying the future. This perception was grounded in different factors. De Jouvenel emphasised in an epistemological sense that there could be no real knowledge about the future. Nonethless, humans could identify desirable futures and actively strive to bring them about. Thus, the image of the open and many futures stemmed from the idea that many futures are creatable and that people can "choose" their own, willed future [25 de Jouvenel, pp 17-32; 6 Andersson]; this reflected a sort of "spirit of optimism"(Aufbruchstimmung) in the 1960s. Furthermore, the perception of many futures was linked to a Cold War context: in the West, the future should be planned but was at the same time open and not determined like from a Marxist point of view.

As mentioned above, futures research was conceptualised by intellectuals and scientists from different disciplines, driven by different methodological viewpoints and ideas, and this was one reason for different labels epitomizing scientific approaches to forecasting, planning and thinking about the future. Whereas Futures Research was more focused on scientific methods, on forecasting and planning, in the USA the term Futurology circulated in a more populist sense, whereas Ossip Flechtheim in the Federal Republic of Germany sought to emphasise the explicit academic character of Futurologie. In the 1970s Futures Studies gained the upper hand as a term that was broader and sought to encompass all aspects of thinking about, forecasting and planning "futures" [69 Masini; 43 Helmer; 29, 30 Flechtheim].

Hence, the field of futures research was fluid. Three different approaches in the 1960s can be identified. First, an empirical and positivistic approach to futures research dominated the scene in the 1960s. Driven by positivism on the level of epistemology and, mostly, by behaviourism, this technologybased approach was mostly epitomized by natural scientists and social scientists. They used trend extrapolations, scenarios, and computer simulations to forecast future developments. One main protagonist was the US futurist Herman Kahn. He was known for so-called war gaming, constructing somehow cynical scenarios about the likely consequences of nuclear war. He argued, confident about the modes of forecasting: "a realistic war game may predict the future, or at least some aspects of it, quite accurately" [56 Kahn \& Mann, p 11-2; see also 57 Kahn; 48 Jantsch]. In West Germany, the Centre Berlin for Futures Research was established by exponents epitomizing the empirical and positivistic approach. When it was founded in 1968, the Centre propagated: "We would like to find acceptable solutions for problems hampering progress of civilisation or that must be reckoned with in the foreseeable future". ${ }^{6}$ The chief executive of the Centre Heinz Hermann Koelle was particularly shaped by technological optimism and an idea of feasibility (Machbarkeitsdenken). The aerospace engineer, who had moved to the USA together with Wernher von Braun in the 1950s, had worked at the NASA George C. Marshall Space Flight Center. After returning to Berlin in 1965, he was engaged in implementing Systems Engineering as a new course of study at the Free University Berlin. In this respect, it was not surprising that Koelle claimed that the Centre Berlin should use computer-based systems analysis which was to be "action-orientated" as well as providing "political decision support".

A second, normative and ontological approach was characterised by reflecting on the future in the framework of a holistic world view. Bertrand de Jouvenel and the German physicist Carl Friedrich von Weizsäcker thought about possible and willed futures in a historical and philosophical perspective, searching for moral ideas of the "good" future and aiming at ordering the social and technological acceleration in a normative perspective. Despite all insecurities it seemed necessary to think about and develop alternative futures so that willed futures could come close to probable futures and there would be sufficient time to plan and act flexibly. "Prévoir suppose que l'on ait d'abord regardé. Well: foreseeing depends on looking", de Jouvenel declared. ${ }^{8}$ Both combined scepticism regarding technology and confidence in the potential of modern science and technology in an ambivalent way, and both understood the futures field as an art, highlighting in Aristotelian tradition the individual skills of the intellectuals thinking about the future in an ontological mode. This was the reason why both avoided using the terms "futures research" and "futurology" but instead spoke of the "art of anticipation" (de Jouvenel) and "Mellontik" [ancient Greek for "in the process of"] (von Weizsäcker). ${ }^{9}$

A third, critical and emancipatory approach was shaped by idealistic, somewhat utopian viewpoints, as epitomized by the German-Austrian historian Robert Jungk, the German political scientist Ossip K. Flechtheim and the Norwegian philosopher and father of peace research Johan Galtung. They were all shaped by a social philosophical and critical

\footnotetext{
${ }^{6}$ First information broschure of "Zentrum Berlin für Zukunftsforschung" (Centre Berlin for Futures Research), undated (1968), Bundesarchiv, B 138,1550 .

${ }^{7}$ Heinz Hermann Koelle, Minutes of the Vorstands-Meeting Centre Berlin for Futures Research, 9th July 1970, Archives of the Institut für Zeitgeschichte, ED 701, 41; see 59 Koelle.

${ }^{8}$ Bertrand de Jouvenel to Edward Cornish, 4th Jan 1975, Bibliothèque Nationale de France, NAF 28143, 297; see 25 de Jouvenel 1967; 101 von Weizsäcker; 102 von Weizsäcker.

${ }^{9}$ De Jouvenel 1967; Carl Friedrich von Weizsäcker, additional paper on founding a Max Planck Institute "zur Untersuchung der Lebensbedingungen der wissenschaftlich-technischen Welt", 15th Feb 1968, Bundesarchiv, B 196, 7168; 102 von Weizsäcker.
} 
epistemology that was close to Critical Theory, and they were moulded by an understanding of society that focused on human beings, an awareness of the development of time in history and a historical-dialectic approach to science, which reflected the role of the scientist in the cognitive process. Moreover, this approach stemmed from a branch of the political left which aspired to emancipate human beings from the constrictive political, economic and spiritual structures of the "system", and thus it was also tied up with emerging peace research. Jungk had published the bestseller "Die Zukunft hat schon begonnen: Amerikas Allmacht und Ohnmacht" ("Tomorrow is already here") in 1952, in which he accused US civilization of an excessive belief in technological progress, domesticating both nature and man [50 Jungk]. In the 1960s he still rejected atomic weapons, but was more open for the promises of the Technical Age. Similarly to Galtung and Flechtheim, he voted in a utopian mode for a "homo novus" (New Man) creating his own future and combining planning and participation [51 Jungk, p. 515; cf 52, 53 Jungk; 55 Jungk \& Galtung; 91 Seefried, p 159-62]. Principally, this approach was inextricably linked with ideas of participation and civil society, stimulating new social movements on a transnational and global scale emerging in the 1960s [109 Wittner; 7 Andersson].

Generally speaking, "Western" futures research in the late 1950s and 1960s was bound up with an idea of feasibility, aiming at combining forecasting and planning a better future. This understanding was part and parcel of the intrinsic code of futures research, encapsulating the principle of cybernetics as a method for transgressing the boundaries separating episteme and techne [39 Hagner p 38-9]. This does not mean that the futures field was shaped by endless optimism as futurists were also aware of the risks that came along with modernity and its perceived accelerated change. However, they were confident that the "futures" were open and could be planned and steered, and this was mostly combined with a positive understanding of technological progress.

\section{Producing future expertise}

Current research on political culture in Western industrialized countries has emphasized that political orientations towards planning and modernization prospered during the 1960s due to the economic "golden age", the rapid growth of science and technology and the breakthrough of Keynesianism [99 van Laak; 27 Doering-Manteuffel; 71, 72 Metzler; 18 Cazes; 74 O'Hara]. In West Germany, conceptions of central planning had been perceived more or less negatively in the 1950s. This was especially due to West German perceptions of the GDR, as the planning principle in itself seemed to epitomize some sort of planned economy (Planwirtschaft). This changed in the mid-1960s. The economic boom played a central role as it seemed to offer new possibilities for action. West German politics came under the sway of new spirit of reform and modernisation, which also aided in the breakthrough of the Keynesian paradigm [72 Metzler, pp 225-366; 81 Ruck]. And this was true both for Social Democrats and Liberals, even for many Christian Democrats and conservative politicians with visions of conservative "modernity" coming to the fore. Politicians from different parties argued that social and technical change had altered the requirements of politics tremendously. Thus it seemed to be necessary for politics to control this change actively, absorbing its implications. Hence, planning attained a somehow enigmatic image in Western industrialized countries, being linked to progress, modernity and "a view of the world at once positivistic, linear and rational, celebrating the machine" [74 O'Hara, p 1; see also 72 Metzler; 95 Süß]. "Rational" politics became a discursive leitmotiv [72 Metzler, p 209-10], and in this rationality could mean both seeking objectivity and the best solution as well as enabling people to decide on a free, reasoned and "enlightened" basis. Hence, planning was linked to some sort of "scientization" of politics, as politics relied more than ever before on scientific and experts' advice [82 Rudloff; generally 77 Raphael].

This met with the aim of futures research to not only do research on the future but also to shape it. It is thus not surprising that futures research tried to contribute its expertise to politics in the 1960s, as will be demonstrated using the following examples of West German futures research and the Federal Government. This applied most by far to the empirical-positivist approach.

First, the protagonists of the critical-emancipatory approach refrained from providing scientific advice to the government. These futurists focused on having an impact on the critical public (in the understanding of Jürgen Habermas), on civil society and social movements. Hence, Jungk and Galtung founded "Mankind 2000", a transnational organisation engaged in thinking about and visualising coming peace and human development transgressing the boundaries of the Cold War. Initially, Jungk planned to organize an international exhibition entitled "A World at Peace" in London in 1964. ${ }^{10}$ The exhibition was designed to deal with utopias of a peaceful future and "visions of a better world" [54 Jungk, p 360]. This plan failed but with Galtung's support Mankind 2000 was set up as a transnational network. Mankind oscillated between acting as an epistemic community and a social movement, from which the "World Future Studies Federation" emerged at the beginning of the 1970s. ${ }^{11}$ Furthermore, Jungk

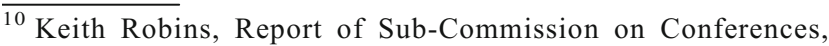
International Confederation for Disarmament and Peace. Report of the Inaugural Congress held at Tyringe, Sweden, Jan 1964, Archives of the Institut für Zeitgeschichte, ED 702, 52.

${ }^{11}$ Summary of Decisions reached at the Mankind 2000 International Meeting held at William Penn House on 24th May 1966. Robert Jungk Bibliothek Salzburg; 55 Jungk \& Galtung; 91 Seefried, pp 195ff; for "epistemic communities" 38 Haas.
} 
concentrated on making an impact on the public by means of publications and on discussing "willed futures" with students as a lecturer at the "Technische Universität" in Berlin. From this emerged the concept of future workshops (Zukunftswerkstätten). In a multilevel model, which in some ways embodied a link between brainstorming and the Delphi method, people were supposed to "invent" their future, i.e. creatively develop it by discussing social problems in a dynamic group process, gathering ideas for solutions and examining their application [24 Dator; 33 Gabor; 91 Seefried, p 167-8].

From the second field, of the normative-ontological approach, Carl Friedrich von Weizsäcker, who believed he had a particular social and political duty as an atomic physicist, continually pushed the boundaries between the functional systems of science and politics. One way in which he did this was via the public, for example by initiating the Göttingen Declaration of Atomic Physicists in 1957. The arcane field of politics became even more important for him, however, as he focused on having a political impact as an expert. Hence, he entered into the public sphere especially when he aimed at increasing the pressure to act on political actors via the media [61 Kraus; 91 Seefried, pp 96-7, 178-9, 349-51]. In the mid1960 s von Weizsäcker extended his thoughts from the "atomic age" to the whole "technical age" [101 von Weizsäcker]. In general, von Weizsäcker regarded the technical development, with its "rapid tempo", ambivalently [102 Weizsäcker, p 68]. On the one hand, the new "basic sciences" from the sphere of the think tanks, such as cybernetics and games theory, fascinated him. On the other hand, he was well aware of the problematic consequences of technical progress, as was reflected in atomic physics. In order to assess the ambivalent consequences of science and technology for the future, he planned in 1967 to found a "Max Planck Institute for Research into Living Conditions in a Scientific-Technical World". The Institute was designed, on the one hand, to do research on the new basic sciences such as cybernetics, and on the other hand to address special topics of direct political relevance, such as global food production and the deterrence system. The Institute should in particular advise the executive in related factual issues. ${ }^{12}$ The Federal Minister of Research Gerhard Stoltenberg supported this plan as he was especially interested in "modern" techniques and knowledge produced at the US Think Tanks. However, von Weizsäcker's Max Planck Institute could not be completely realised. His concept encountered resistance from industry representatives in the senate of the Max Planck Institute, which feared that the industry

\footnotetext{
${ }^{12}$ Von Weizsäcker, Bargmann, von Bismarck, Heimpel, Gerlach, Heisenberg, Vorschlag zur Gründung eines Max-Planck-Instituts zur Erforschung der Lebensbedingungen der wissenschaftlich-technischen Welt, 1st Nov 1967; von Weizsäcker, Ergänzungen zu dem Antrag, 15th Feb 1968. Bundesarchiv, B 196, 7168.
}

could be restricted in its innovative freedom by "leftist" exponents of futures research and peace research. Von Weizsäcker was thus forced to limit the Max-Planck-Institute in Starnberg in its advisory capacity and to reduce its size [91 Seefried, p 351-4; 64 Leendertz, p 20; 32 Futurologie].

The project "War Consequences and War Prevention" of the Max Planck Institute attained particular political significance. It had already been begun under the aegis of von Weizsäcker in the research department of the "Association of German Academics (Vereinigung Deutscher Wissenschaftler)", supported by the Volkswagen Foundation. This project examined in various scenarios the effects of a nuclear war on West German territory [2 Afheldt]. A task force designed a computer-assisted simulation model that divided the territory of West Germany into zones and forecast in war scenarios potential human losses, health casualties and housing and industrial costs. Furthermore, the group dealt with the deterrent strategy and developed scenarios for ranges of variations of strike likelihoods of new weapons, such as anti-ballistic missiles. The simulations showed that in none of the scenarios did the Federal Republic possess a real defensive potential, i.e. the capacity to prevent an opponent from carrying out his threat by use of military means. Ultimately, the group drew up three global qualitative scenarios: a duopoly as the most obvious option would suffer from the difficulty of maintaining the balance between the two powers. A monopoly as the second scenario was barely conceivable without a large-scale war. The third option was a global political system consolidated by international organisations that would initiate disarmament [103 von Weizsäcker; 3 Afheldt]. This option had already been designed by von Weizsäcker in 1963 entitled "Weltinnenpolitik" [100 von Weizsäcker, p 131]. Thus, the project confirmed von Weizsäcker's thesis, that technical developments made a permanent stabilisation of the deterrent system almost impossible. From an epistemological point of view, the project had admittedly been designed in such a way that a confirmation of von Weizsäcker's theses was not very surprising. Fundamentally, however, the project successfully connected peace research and futures research, and it had both a normative and an action-orientated reference point. As it questioned the deterrent system and called for promoting détente, the study backed the architects of the new eastern policy (Neue Ostpolitik), the new Chancellor Willy Brandt and State Secretary Egon Bahr, with whom von Weizsäcker stood in contact. ${ }^{13}$ However, this project led von Weizsäcker and the Max Planck Institute further into the realm of peace (and not futures) research [see 46 Hutchinson \& Inayatullah].

\footnotetext{
${ }^{13}$ Weizsäcker to Brandt, 21th March 1972, and correspondence with Egon Bahr. Archives of the Max Planck Society, Weizsäcker Papers, Files 6 and 15.
} 
Third, protagonists from the field of an empirical-positivist approach attempted most strongly to provide scientific policy advice. The Centre Berlin for Futures Research actively offered itself up for advising politics. The Centre claimed that it could draw up research planning modelling but also be active in the fields of budget planning as well as constructing traffic planning models, population models and global government models. ${ }^{14}$ It is clear that it was no longer the object - the "what" - that was decisive but the "how": any topic appeared to be workable because in the centre of focus was the method, and here, above all, the computer-based simulation model.

The Centre Berlin established contact in particular with the new planning department of the Federal Chancellery. The planning department had been set up against the backdrop of fresh scientific, political and also media interest in a "modern" and "rational" form of governance. The Chancellery had already come under fire during the "grand coalition" 1966 to 1969: it allegedly fulfilled its duties as an organ of coordination, information and control insufficiently, as it forewent "modern leadership staffs", "political planning and systematic data management" [110 Zundel; see 95 Süß]. Therefore, from 1967 on, a new planning staff should ponder the planning of procedures, i.e. the organisation of political processes, as well as task scheduling, i.e. coordination of fields of activity with regard to a catalogue of aims. This was bound up with setting up the "Project Group for Government and Administrative Reform". That panel, consisting of representatives of the Chancellery and other ministries, was to submit proposals for better coordination between the individual ministries [96 Süß]. The Brandt government which came to power in 1969 then expanded the planning staff into a planning department. This was completely in line with the proposed reform policy: according to Willy Brandt in his first government declaration, the government had to "begin with itself when talking of reforms". The Federal Chancellery and the ministries should be "modernised in their structures and thus in their work" [17 Brandt, p 261]. Subsequently, Chancellery Minister Horst Ehmke, who acted with a striking, technically-friendly reform vigour, turned the planning policy into the preferred field of activity [26 Der Macher; 72 Metzler, p 364-5]. According to Ehmke and the new departmental head, political scientist Reimut Jochimsen, planning should now be anchored in all sections via so-called planning plenipotentiaries. Thus, planning now incorporated not only economic policy (in the sense of Keynesianism) but all political fields. Above and beyond this, the temporal horizon of planning was now extended and conceived for the medium to long term, for between 5 and 15 years. As planning was predestined to develop "strategic concepts for the solution of complex

\footnotetext{
${ }^{14}$ First information broschure of the "Zentrum Berlin für Zukunftsforschung"(Centre Berlin for Futures Research). Bundesarchiv, B 138, 1550.
}

political problems under consideration of their contexts and longer-term consequences", the connection to systems analytical models, which explored the inner correlations of the system, was obvious. ${ }^{15}$

Koelle of the Centre Berlin contacted Ministerialrat Adolf Theis from the planning department of the Chancellery, who was also the chairperson of the Project Group for Government and Administrative Reform. Theis invited Koelle to give a paper before the Project Group for Government and Administrative Reform. After Koelle's presentation, Theis stated almost euphorically that the Centre Berlin would offer expertise in the area of planning, data preparation, decision models and operations research "that is, at least currently, unique in West Germany". ${ }^{16}$ Thus, the Centre Berlin for Futures Research received various commissions from the Federal Government. For one, the Project Group for Government and Administrative Reform participated in the Berlin Simulation Model (BESI), which the Centre Berlin for Futures Research drew up for the Berlin state government as a model "for studying the development and restructuring of large cities". Koelle and seven other academics from an interdisciplinary team constructed an early warning system that was initially designed to divide the "'condition' of a social system" into individual activity sectors and then split these up into components. At the same time, indicators should be used to gather the most important characteristics of this condition. The thoroughness of this gathering was, according to Koelle, who completely underestimated the social and political complexities, "primarily a question of applied effort". Beyond that, the decision-makers would have to develop short-, medium- and long-term aims; here, for example, the government declaration of the lord mayor of West-Berlin, divided into variables, could be fed in. The decision-makers should also determine target values for the indicators, concepts of time for when the target values should be reached, and thresholds for defining the parameters of the aims. The fact that a government declaration was difficult to quantify and divide into factors was evidently not considered. After the indicators were assigned with concrete data, a "warning system" was to issue a timely signal if one of the indicators threatened to exceed the set thresholds. The information system was to reproduce and simulate the possible consequences of planned decisions. ${ }^{17}$ Thus, the simulation model was based on the

\footnotetext{
${ }^{15}$ Chancellery (Bundeskanzleramt), Planungsstab, Ausbau der politischen Planung im BKA, 20th Oct 1969, Bundesarchiv, B 136, 14064; see Jochimsen 1971; Süß, 2003, pp 361-4; 72 Metzler, p. 354-6.

${ }^{16}$ Project Group for Government and Administrative Reform, Theis, 23th Nov 1970, cited in paper Seiler, 16th May 1973, Bundesarchiv, B 106, 49611; Minutes of the meeting of the "Vorstand" Centre Berlin for Futures Research held on 9th July 1970, Archives of the Institut für Zeitgeschichte, ED 701, 40.

${ }^{17} 15$ Birreck \& Koelle; see Chancellery, Minutes planning meeting held on 12th June 1970, Bundesarchiv, B 136, 14064; Minutes Bundeskanzleramt meeting held on 3rd Dec 1970, ibid, 14536.
} 
certainty that it could quantify and formalise social processes, and this concept epitomised nothing less than a euphoria of steering.

Second, the Centre Berlin was commissioned by the planning department of the Chancellery and the Project Group for Government and Administrative Reform to handle the project PLABUND (Planning Aid in the Federal Administration). For this it received the princely sum of two million marks. The overall concept, according to the Centre Berlin, was guided by the idea that "planning processes in the field of federal administration $[\ldots]$ can only be decisively improved by means of specific planning aid that has been coordinated in its functional profile". ${ }^{18}$ Thus, the project aimed at "rationalisation", i.e. the creation of scientificity and efficiency in process planning. The core was the project EIPE (Experimental Integrating Planning and Decision-making System), led by the sociologist Helmut Klages. It aimed at developing "foundations and design criteria for the construction of an interagency information system in the area of government and administration". According to the abstruse formulations, it attempted to do research on the "space for deliberation of preparatory work for decisions" within the basic units of the federal administration, i.e. the decision-making processes and the scope of action. So far, the preparation of decisions in the individual sections seemed to impede the decision-makers, i.e. the ministers, in making assessments within the overall political concept. In this way, "non-rational determinants of politicaladministration action" were to be reduced. ${ }^{19}$ The project team ascertained "fundamental assumptions and allocated information holdings" of the administrators "on social, economic and political prerequisites". This was to take place empirically by means of "participatory observation". Staff of the Centre Berlin (two political scientists, a sociologist and a economist) was therefore appointed for 3 months to four ministries as assistant administrators. Parallel to this, intensive interviews of the administration with the Centre staff were to take place. The information acquired was to be gathered in a "categorial filing arsenal", i.e. quantified. ${ }^{20}$ In principle, it was thus attempted to gauge information flow within the ministry, to rationalise working processes and make them more transparent, and to examine the room for manoeuvre possessed by the administration and to what extent the administration could be synchronised with the political line. On this basis, an

\footnotetext{
${ }_{18}$ Centre Berlin for Futures Research, Outline on PLABUND, 26th April 1973, Bundesarchiv, B 106, 54323.

${ }^{19}$ Centre Berlin, Outline on EIPE, 13th April 1973, Bundesarchiv, B 106, 54323, and Centre Berlin, Outline on EIPE, undated, ibid, 49611; Project Group, Paper Randel, 22nd Sept 1972, ibid; see for this Seefried 2010, p. $131-4$.

${ }^{20}$ Centre Berlin, Outline on EIPE, 13th April 1973, Bundesarchiv, B 106, 54323; Project Group, Randel, Paper on Meeting with Centre Berlin held on 2nd Jan 1973, ibid, 49611.
}

information system should be developed that would be of value to an early warning system.

Yet the consultation process turned out to be sobering. BESI was cancelled whilst still in its pilot phase because the Project Group for Government and Administrative Reform and the Berlin state government discontinued the funding step by step in 1972 and 1974, respectively. EIPE quickly met with resistance from the ministerial bureaucracy in the Chancellery, which criticised the lack of administrative experience among the futures researchers. The Centre Berlin for Futures Research argued that the administration insulated itself "against the general availability of experience and background knowledge". ${ }^{21}$ The approach of measuring the room of manoeuvre of the administration in order to bring it more strongly in line with politics did indeed lead to concerns that leeway could be restricted. Theis, who had initially been so positive, criticised the lack of intelligibility on the part of the texts. Ultimately the Project Group argued that the undertaking lacked "the necessary autonomy". 22 The Centre Berlin would have to be satisfied with continuing to accept ideas from the Federal Government and convert them into the "inflated ZBZ [= Centre Berlin] language". ${ }^{23}$ The Project Group for Government and Administrative Reform now focused on a study carried out by the consultants McKinsey. In contrast to the Centre Berlin, McKinsey was seen as having a "pragmatic approach". ${ }^{24}$ The "practical use" of EIPE, on the other hand, was called into question. $^{25}$

Consequently, the Centre Berlin's policy advice to the government quickly ran into problems. Both the computerassisted simulation, which simulated and anticipated the consequences of decisions (BESI), as well as consulting in the area of process planning (EIPE), ended more or less without success. It was of central importance that the interaction between the futures researchers, politics and the ministerial bureaucracy was full of tension. This had its roots in the inflated expectations that politicians had in futures research as well as those which futures researchers had in themselves. The Centre Berlin declared itself responsible for all political fields and yet always competed with specialists. The futures researchers overestimated the capacity of systems analytical models for solving problems and the rules and system character of social structures and processes. Furthermore, they

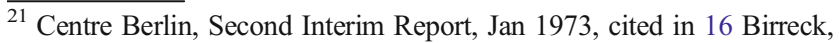
Kolb, Rosolski, p 14.

${ }^{22}$ Project Group, Thomas paper, 19th Sept 1972, Randel paper, 22th Sept 1972, Seiler Paper, 16th May 1973, Bundesarchiv, B 106, 49611.

${ }^{23}$ Project Group, Minutes of a meeting held on 26th April 1973, Bundesarchiv, B 106, 49611.

${ }^{24}$ German Federal Ministry of Research and Technology, Minutes of PLABUND meeting held on 30th May 1973, Bundesarchiv, B 106, 49611; Project Group to Jochimsen, 27th Apr 1971, Archiv für soziale Demokratie, Jochimsen Papers, 1/RJAC0000039-40.

${ }^{25}$ Project Group, Minutes of EIPE meeting, 2nd March 1973, Bundesarchiv, B 106, 49611.
} 
spoke a different language to the ministerial bureaucracy; the Centre Berlin had developed its own system language permeated with cybernetics, which was not compatible with the ministerial bureaucracy, most of whom had a background in law [40 Hegelau, p 169; 9 Bebermeyer, p 18-9]. It was decisive that the Centre Berlin assumed that it could gather problem scenarios and decision-making processes "completely" and quantify them. Model simulations attempt to imitate and to visualise the complexity of reality, but they can supply only fragmentary knowledge on a virtual model world, which cannot depict social complexity [65 Lenhard]. In an engineering mentality of feasibility, the Centre Berlin ignored the fact that decision-making in politics cannot be completely modelled or, even more so, quantified [76 Porter]. It was ultimately overlooked that the interaction between state guidance, societal change and the influence of experts - experts such as the Centre Berlin itself - were much more complex than it was possible to depict in a model [91 Seefried, pp 3935; 84 Schanetzky]. Fundamental problems of the planning department certainly also played a role. The Project Group for Government and Administrative Reform was disbanded, not least due to criticism of the far-reaching planning projects of the Chancellery formed in the Ministries that feared a reduction in their influence. In the cabinet, in which the view of the planning department as a "child's steam engine" did the rounds, the ambitious Ehmke came under pressure. Finance Minister Helmut Schmidt, an opponent of the planning concepts, prevented a direct coordination of financial and task planning between the Finance Ministry and the Chancellery and, not least as a result of rivalries in the cabinet, Ehmke had to switch to the Technology Ministry in 1972 [47 Jäger, p 33; 95 Süß, pp 369-77; 85 Schatz]. It furthermore became clear in summer 1971 that the budget did not offer sufficient funds for all the reform projects that had been drawn up by the Brandt government. The oil crisis of 1973 and the economic crisis then pulled the rug out from under the planning department, as the planning group was not "suitable for moderating conflicts of allocation against the backdrop of limited resources" [95 Süß, p 375].

However, the Centre Berlin for Futures Research learned from these problems. A policy paper from 1975, composed by the new deputy chairperson Rainer Mackensen, a sociologist, regarded the task of futures research as doing the spadework for political decision-making in the interests of the people. It conducted research, he continued, on possible developments, the extent to which they could be evaluated vis-à-vis various objectives and the extent to which they could be influenced by public decisions. Improving the life of many seemed to be much more important than the "impressive demonstration of technical capacity". For this, futures research should use tangible social scientific, systems analytical and technical processes. Futures research helped to utilise the potential for a "more comprehensive consideration of public decisions" [68
Mackensen]. The distancing from the phase of model simulation is very apparent here. Futures research was now aimed at integrating systems analysis and modelling into a mixture of methods under the banner of a reflected, socially-orientated understanding of the "discipline". This understanding was pragmatic because it balanced the possibilities and limits of futures research and realistically assessed them.

\section{Conclusions}

The founding years of futures research were turbulent. The field of futures research was conceptualised in a process of transnational circulation of knowledge in Western Europe and the USA between the late 1950s and the late 1960s. The different approaches to thinking about, forecasting and planning the future shared the conviction that many possible futures existed to be investigated and created. And they shared the perception of technological and social acceleration derived from the techno-scientific developments that had occurred since 1945, which had to be steered by using modern and "rational" methods and techniques mostly originating from US think tanks.

The exponents of the futures field produced scientific expertise for policy development and strategic planning. The background to this was a far-reaching understanding of planning derived from politics, which partly possessed euphoric traits. Futures research could doubtlessly attract the interest of the Federal Government because it appeared to be modern and "rational", interdisciplinary and very much "Western" and American influenced. If one looks at the knowledge formats and methods of futures research offered for scientific policy advice, the exponents of a critical-emancipatory approach (such as Jungk) did not regard it as its principal aim to generate employable knowledge but rather to focus on the critical public and to discuss alternative futures with the "citizen". Regarding the normative-ontological field, the MaxPlanck-Institute was limited in its political advisory capacity but fulfilled autonomously the "war consequences" study that combined computer simulations and qualitative scenarios and produced employable knowledge. Ultimately, the Centre Berlin for Futures Research represented the positivist-empirical approach. Even beyond the examples already cited above, it constructed broad-brush models, which used cyberneticinspired computer simulations to calculate the consequences of alternative decisions and drew up Systems Analysis studies of organisational and procedural structures. It was precisely here that a degree of certainty dominated whereby futures research would be able to forecast and steer the future exactly. This certainty possessed scientistic traits and had a euphoric touch. Hence, the Centre Berlin's policy advice to the government quickly ran into problems as the futures researchers overestimated the capacity of systems analysis and modelling 
as well as the system character of social structures and processes.

In the early 1970s, the confidence of many futures researchers in modelling and steering the future was shattered. One reason for this were the outlined problems in utilizing future expertise in government. In general, futures research underwent a tremendous change in the early 1970s. The book "The Limits to Growth" from 1972 epitomized a breakthrough of new modes of thinking about the future, as it conveyed both an "old" belief in computer simulations and global planning as well as a deep questioning of economic growth and technology. Significant sections of futures research came under the sway of an orientation towards ecology and human beings, their needs and values, rejecting a "cool" techno-scientific and "material"-based understanding of progress [96 Seefried]. As a result, major strands of futures research in the 1970s abandoned large-scale and quantitative-based concepts of steering the future, developing instead a pragmatic and human-centred approach to thinking about and planning the future.

Open Access This article is distributed under the terms of the Creative Commons Attribution License which permits any use, distribution, and reproduction in any medium, provided the original author(s) and the source are credited.

\section{References}

1. Abella A (2008) Soldiers of reason. The RAND Corporation and the Rise of the American Empire. Harcourt, Orlando

2. Afheldt H (1971) Analyse der Sicherheitspolitik durch Untersuchung der kritischen parameter. In: von Weizsäcker CF, Afheldt $\mathrm{H}$ (eds) Kriegsfolgen und Kriegsverhütung. Hanser, München, pp 23-74

3. Afheldt H (1971) Entwicklungstendenzen der Sicherheitspolitik in Europa und umfassendere Ansätze zur Friedenssicherung. In: von Weizsäcker CF, Afheldt H (eds) Kriegsfolgen und Kriegsverhütung. Hanser, München, pp 417-453

4. Agar J (2003) The government machine. A revolutionary history of the computer. MIT Press, Cambridge

5. Amadae SM (2003) Rationalizing capitalist democracy. The cold war origins of rational choice liberalism. University of Chicago Press, Chicago

6. Andersson J (2006) Choosing futures. Alva Myrdal and the construction of Swedish futures studies 1967-1972. Int Rev Soc Hist $51: 277-295$

7. Andersson J (2012) The great future debate and the struggle for the world. Am Hist Rev 117(5):1411-1430

8. Ash MG (2002) Wissenschaft und Politik als Ressourcen füreinander. In: vom Bruch R, Kaderas B (eds) Wissenschaften und Wissenschaftspolitik. Bestandsaufnahmen zu Formationen, Brüche und Kontinuitäten im Deutschland des 20 Jahrhunderts. Steiner, Stuttgart, pp 32-51

9. Bebermeyer H (1974) Regieren ohne Management? Planung als Führungsinstrument moderner Regierungsarbeit. Verlag Bonn Aktuell, Stuttgart

10. Beck U, Bonß W (1989) Verwissenschaftlichung ohne Aufklärung? Zum Strukturwandel von Sozialwissenschaft und Praxis. In: Beck
U, Bonß W (eds) Weder Sozialtechnologie noch Aufklärung? Analysen zur Verwendung sozialwissenschaftlichen Wissens. Suhrkamp, Frankfurt a.m., pp 7-45

11. Bell D (1964) Twelve modes of prediction. A preliminary sorting of approaches in the social sciences. Daedalus 93(3):845-880

12. Bell W (2003) Foundations of futures studies. History, purposes, and knowledge. Vol. 1, new edition. Transaction Publ, New Brunswick

13. Berger G (1957) L'accélération de l'histoire es ses consequences. In de Bourbon Busset et al. (eds) De la prospective. Textes fondamentaux de la prospective française 1955-1966, Paris 2007, 63-72

14. Berghahn VR (2004) Transatlantische Kulturkriege. Shepard Stone, die Ford-Stiftung und der europäische Antiamerikanismus. Franz Steiner, Stuttgart

15. Birreck M, Koelle HH (1971) Warnsystem bezüglich der lebensfähigkeit von Berlin (West). Definitionsstudie. Anal Prognosen Welt Morgen 3(15):21-22

16. Birreck M, Kolb D, Rosolski R (1976) Einsatz von Planungsmodellen in der Verwaltung. Analyse der Pilotprojekte ENIS und ZIEBUV und Untersuchung der Möglichkeiten ihres Einsatzes in weiteren Bereichen der Verwaltung. Berlin

17. Brandt W (1979) Regierungserklärung, 28 Oct 1969. In: von Beyme K (ed) Die großen Regierungserklärungen der deutschen Bundeskanzler von Adenauer bis Schmidt. Hanser, München, pp 250-281

18. Cazes B (1991) Un Demi-Siècle de planification indicative. In: Asselain J, Lévy-Leboyer M, Casanova J (eds) Entre l'Etat et le marché. L'économie française des années 1880 à nos jours. Gallimard, Paris, pp 473-506

19. Coleman P (1989) The liberal conspiracy. The congress for cultural freedom and the struggle for the mind of postwar Europe. The Free Press, New York

20. Collins MJ (2002) Cold war laboratory. RAND, the Air Force, and the American State, 1945-1950. Smithsonian Institution Press, Washington, D.C

21. Cornish E (1977) The Study of the Future. An Introduction to the Art and Science of Understanding and Shaping tomorrow's World. World Future Society, Washington, D.C.

22. Dard O (2008) Bertrand de Jouvenel. Perrin, Paris

23. Daston L (1998) Die Kultur wissenschaftlicher Objektivität. In: Oexle OG (ed) Naturwissenschaft, Geisteswissenschaft, Kulturwissenschaft. Einheit, Gegensatz, Komplementarität? Wallstein, Göttingen, pp 11-39

24. Dator J (1993) Zukunftswerkstätten, soziale Erfindungen und der lange Atem. In: Canzler W (ed) Die Triebkraft Hoffnung. Robert Jungk zu Ehren, Weinheim, pp 104-111

25. de Jouvenel B (1967) Die Kunst der Vorausschau. (Orig. L'art de la conjecture, 1964). Luchterhand, Neuwied

26. Der Macher (1971) Der Spiegel 6: 28-42

27. Doering-Manteuffel A (2008) Ordnung jenseits der politischen Systeme. Planung im 20. Jahrhundert. Gesch Ges 34:398-406

28. Felt U (2002) Wissenschaft, Politik und Öffentlichkeit. Wechselwirkungen und Grenzziehungen. In: Ash MG, Stifter C (eds) Wissenschaft, Politik und Öffentlichkeit. Von der Wiener Moderne bis zur Gegenwart. WUV, Wien, pp 47-72

29. Flechtheim OK (1966) History and futurology. Hain, Meisenheim am Glan

30. Flechtheim OK (1968) Futurologie. Möglichkeiten und Grenzen. Heinrich-Heine-Verlag, Frankfurt

31. Fortun M, Schweber S (1993) Scientists and the legacy of the World War II. The case of operations research (OR). Soc Stud Sci 23:595-642

32. Futurologie. Vorauswissen ist Macht (1969) Der Spiegel 46: 204-207

33. Gabor D (1963) Inventing the future. Secker and Warburg, London

34. Galison P, Hevly BW (eds) (1992) Big science. The growth of largescale research. Stanford University Press, Stanford 
35. Ghamari-Tabrizi S (2000) Simulating the unthinkable. Gaming future war in the 1950s and 1960s. Soc Stud Sci 30(2):163-223

36. Gieryn TF (1983) Boundary-work and the demarcation of science from Non-science. Strains and interests in professional ideologies of scientists. Am Sociol Rev 48(6):781-795

37. Gordon TG, Helmer O (1964) Social technology. Report on a longrange forecasting study. Rand, Santa Monica

38. Haas PM (1992) Introduction. Epistemic communities and international policy coordination. Int Organ 46(1):1-35

39. Hagner M (2008) Vom Aufstieg und Fall der Kybernetik als Universalwissenschaft. In: Hagner M, Hörl E (eds) Die Transformation des Humanen. Beiträge zur Kulturgeschichte der Kybernetik. Suhrkamp, Frankfurt, pp 38-72

40. Hegelau H (1977) Die Arbeit der Projektgruppe "Regierungs- und Verwaltungsreform"als Beispiel einer Kooperation zwischen Verwaltung und Verwaltungswissenschaft. In: Wissenschaftszentrum Berlin (ed) Interaktion von Wissenschaft und Politik. Campus, Frankfurt, pp 166-188

41. Heims SJ (1993) Constructing a social science for postwar America. The cybernetics group 1946-1953. MIT Press, Cambridge

42. Helmer O (1967) Analysis of the future. The Delphi method. Rand, Santa Monica

43. Helmer O (1975) An agenda for futures research. Futures 7(1):3-14

44. Hochgeschwender M (1998) Freiheit in der Offensive? Der Kongress für Kulturelle Freiheit und die Deutschen. Oldenbourg, München

45. Hunt L (2008) Measuring time, making history. Central European University Press, Budapest

46. Hutchinson FP, Inayatullah S (2010) Futures studies and peace studies. In: Young N (ed) The Oxford International encyclopedia of peace, vol 2. Oxford Univ. Press, Oxford

47. Jäger W (1986) Die Innenpolitik der sozial-liberalen Koalition 1969-1974. In: Bracher KD, Jäger W, Link W (eds) Republik im Wandel, 1969-1974. Die Ära Brandt. Deutsche Verlags-Anstalt. F.A. Brockhaus, Stuttgart, pp 15-160

48. Jantsch E (1967) Technological forecasting in perspective. A framework for technological forecasting, its techniques and organisation. A description of activities and an annotated bibliography. Organisation for Economic Co-operation and Development, Paris

49. Jochimsen R (1971) Die Artisten im Kanzleramt-planend. Werden. Jahrbuch für die Gewerkschaften: 39-44

50. Jungk R (1952) Die Zukunft hat schon begonnen. Amerikas Allmacht und Ohnmacht. Scherz \& Goverts, Stuttgart, English: Tomorrow is already There, 1954

51. Jungk R (1964) Gesucht: ein neuer Mensch. Skizze zu einem Modell des Planers. In: Jungk R, Mundt HJ (eds) Der Griff nach der Zukunft. Desch, Munich, pp 505-516

52. Jungk R (1968/69) Technological forecasting as a tool of social strategy. Analysen und Prognosen über die Welt von morgen 1(2): $10-13$

53. Jungk R (1969) Damit die Zukunft nicht aufhört. In Jungk R (ed) Menschen im Jahr 2000. Frankfurt, pp 9-10

54. Jungk R (1993) Trotzdem. Mein Leben für die Zukunft. Hanser, München

55. Jungk R, Galtung J (eds) (1969) Mankind 2000. Allen \& Unwin, London

56. Kahn H, Mann I (1957) War Gaming. Rand Paper. http://www.rand. org/content/dam/rand/pubs/papers/2006/P1167.pdf. Accessed 20 August 2013

57. Kahn H, Wiener AJ (1968) The year 2000. A framework for speculation on the next 33 years. Molden, London

58. Kirby MW (2003) Operational research in war and peace. The British experience from the 1930s to 1970. Imperial College Press, London, pp 66-92
59. Koelle HH (1994) Werden und Wirken eines deutschamerikanischen Raumfahrt-Professors. Wiss.-und-Technik-Verlag Gross, Berlin

60. Koselleck R (1985) Space of experience and "horizon of expectation". Two historical categories. In: Koselleck R (ed) Futures past. On the semantics of historical time. Cambridge Mass, London, pp 255-275, Orig. German 1979

61. Kraus E (2001) Von der Uranspaltung zur Göttinger Erklärung. Otto Hahn, Werner Heisenberg, Carl Friedrich von Weizsäcker und die Verantwortung des Wissenschaftlers. Königshausen \& Neumann, Würzburg

62. Kreibich R, Canzler W, Baumeister K (eds) (1991) Zukunftsforschung und Politik in Deutschland, Frankreich, Schweden und der Schweiz. Beltz, Weinheim

63. Latham ME (2003) Modernization, international history, and the cold war world. In: Engerman DC, Gilman N, Haefele MH et al (eds) Staging growth. Modernization, development, and the global cold war. University of Massachusetts Press, Amherst, pp 1-22

64. Leendertz A (2010) Die pragmatische Wende: Die Max-PlanckGesellschaft und die Sozialwissenschaften 1975-1985. Vandenhoeck und Ruprecht, Göttingen

65. Lenhard J, Küppers G (2007) Computersimulationen -Wissen über eine imitierte Wirklichkeit. In: Weingart P, Carrier M, Krohn W (eds) Nachrichten aus der Wissensgesellschaft. Velbrück-Wiss, Weilerswist, pp 111-138

66. Leonard R (2010) Von Neumann, Morgenstern, and the creation of game theory. From chess to social science, 1900-1960. Cambridge Univ. Press, Cambridge

67. Leslie SW (1994) Science and politics in cold war America. In: Jacob MC (ed) The politics of western science, 1640-1990. Atlantic Highlands, N.J, pp 199-233

68. Mackensen R (1975) Ist langfristige Sozialplanung aktuell? Anal Prognosen Welt Morgen 7(38):4-5

69. Masini E (2000) Futures research and sociological analysis. In: Quah SR, Sales A (eds) The international handbook of sociology. Thousand Oaks, London, pp 491-505

70. McHale J, McHale MC (1977) The futures directory. An international listing and description of organizations and individuals active in futures studies and long-range planning. IPC Science and Technology Press; Westview Press, London

71. Metzler G (2004) Demokratisierung durch Experten? Aspekte politischer Planung in der Bundesrepublik. In: Haupt HG, Requate J (eds) Aufbruch in die Zukunft. Die 1960er Jahre zwischen Planungseuphorie und kulturellem Wandel. DDR, CSSR und Bundesrepublik Deutschland im Vergleich, Weilerswist, pp 267-287

72. Metzler G (2005) Konzeptionen politischen Handelns von Adenauer bis Brandt. Politische Planung in der pluralistischen Gesellschaft. F. Schöningh, Paderborn

73. Neumann J, Morgenstern O (1953) Theory of games and economic behavior, 3rd edn. Princeton University Press, Princeton

74. O'Hara G (2007) From dreams to disillusionment. Economic and social planning in 1960s Britain. Palgrave Macmillan, Houndmills

75. Pircher W (2008) Im Schatten der Kybernetik. Rückkopplung im operativen Einsatz: "operational research". In: Hagner M, Hörl E (eds) Die Transformation des Humanen. Beiträge zur Kulturgeschichte der Kybernetik. Suhrkamp, Frankfurt, pp 348-376

76. Porter TM (1995) Trust in numbers. The pursuit of objectivity in science and public life. Princeton, NJ

77. Raphael L (1996) Die Verwissenschaftlichung des Sozialen als methodische und konzeptionelle Herausforderung für eine Sozialgeschichte des 20 Jahrhunderts. Gesch Ges 22:165-193

78. Rau EP (2000) The adoption of operations research in the United States during world war II. In: Hughes AC, Hughes TP (eds) Systems, experts, and computers. The systems approach in 
management and engineering, world war II and after. MIT Press, Cambridge, pp 57-92

79. Rescher N (2006) The Berlin school of logical empiricism and its legacy. Erkenntnis 64:281-304

80. Ronge V (1989) Verwendung sozialwissenschaftlicher Ergebnisse in institutionellen Kontexten. In: Beck U, Bonß W (eds) Weder Sozialtechnologie noch Aufklärung? Analysen zur Verwendung sozialwissenschaftlichen Wissens. Suhrkamp, Frankfurt, pp 332-354

81. Ruck M (2004) Westdeutsche Planungsdiskurse und Planungspraxis der 1960er Jahre im internationalen Kontext. In: Haupt HG, Requate J (eds) Aufbruch in die Zukunft. Die 1960er Jahre zwischen Planungseuphorie und kulturellem Wandel. DDR, CSSR und Bundesrepublik Deutschland im Vergleich, Weilerswist, pp 289-325

82. Rudloff W (2004) Verwissenschaftlichung der Politik? Wissenschaftliche Politikberatung in den sechziger Jahren. In: Collin P, Horstmann T (eds) Das Wissen des Staates. Geschichte, Theorie und Praxis. Nomos, Baden-Baden, pp 216-257

83. Saretzki T (2005) Welches Wissen - welche Entscheidung? Kontroverse Expertise im Spannungsfeld von Wissenschaft, Öffentlichkeit und Politik. In: Bogner A, Torgersen H (eds) Wozu Experten? Ambivalenzen der Beziehung von Wissenschaft und Politik. VS Verlag für Sozialwissenschaften, Wiesbaden, pp 345-369

84. Schanetzky T (2007) Die große Ernüchterung Wirtschaftspolitik, Expertise und Gesellschaft in der Bundesrepublik 1966 bis 1982. Akademie, Berlin

85. Schatz H (1977) Funktionsbedingungen und Konfliktsituationen verwaltungswissenschaftlicher Forschung und Beratung, dargestellt am Beispiel der Projektgruppe Regierungs- und Verwaltungsreform. In: Wissenschaftszentrum Berlin (ed) Interaktion von Wissenschaft und Politik. Campus, Frankfurt, pp 189-226

86. Schirrmacher A (2008) Nach der popularisierung. Zur relation von wissenschaft und öffentlichkeit im 20 Jahrhundert. Gesch Ges 34 : 73-95

87. Schmidt-Gernig A (2002) The cybernetic society. Western future studies of the 1960s and 1970s and their predictions for the year 2000. In: Cooper RN, Layard PRG (eds) What the future holds. Insights from social science. MIT Press, Cambridge, pp 233-259

88. Schmidt-Gernig A (2003) Forecasting the future. Future studies as international networks of social analysis in the 1960s and 1970s in Western Europe. In: Gienow-Hecht JCE, Schumacher F (eds) Culture and international history. Berghahn, New York, pp 157-172

89. Seefried E (2010) Experten für die planung? “zukunftsforscher”als berater der bundesregierung 1966-1972/73. Arch Sozialgesch 50: $109-152$

90. Seefried E (2011) Towards the 'limits to GROWTH'? the book and its reception in west Germany and great Britain 1972/73. Bull Ger Hist Inst Lond 33(1):3-37

91. Seefried E (2013) Zukünfte. Zukunftsforschung und Expertise der 1960er und 1970er Jahre. Ludwig Maximilians University Munich Habilitation Thesis

92. Seybold P (1980) The Ford Foundation and the Triumph of Behaviorialism in American Political Science. In: Arnove RF (ed) Philanthropy and cultural imperialism. The foundations at home and abroad. G.K. Hall, Boston, pp 269-303

93. Sozialdemokratische Partei Deutschlands (1969) Sozialdemokratische Perspektiven im Übergang zu den siebziger
Jahren. In: Ehmke H (ed) Perspektiven. Rowohlt, Reinbek, pp 11170

94. Steinmüller K, Steinmüller K, Kreibich R, Zöpel C (2000) Zukunftsforschung in Europa. Ein Abriß der Geschichte. In: Zukunftsforschung in Europa. Ergebnisse und Perspektiven. Nomos, Baden-Baden, pp 37-54

95. Süß W (2003) "Wer aber denkt für das Ganze?”Aufstieg und Fall der ressortübergreifenden Planung im Bundeskanzleramt. In: Frese M, Paulus J, Teppe K (eds) Demokratisierung und gesellschaftlicher Aufbruch. Die sechziger Jahre als Wendezeit der Bundesrepublik. Schöningh, Paderborn, pp 349-377

96. Süß W (2004) "Rationale Politik"durch sozialwissenschaftliche Beratung? Die Projektgruppe Regierungs- und Verwaltungsreform 1966-1975. In: Fisch S, Rudloff W (eds) Experten und Politik. Wissenschaftliche Politikberatung in geschichtlicher Perspektive. Duncker \& Humblot, Berlin, pp 329-348

97. Tanner J (2008) Komplexität, Kybernetik und Kalter Krieg. "Information"im Systemantagonismus von Markt und Plan. In: Hagner M, Hörl E (eds) Die Transformation des Humanen. Beiträge zur Kulturgeschichte der Kybernetik. Suhrkamp, Frankfurt, pp 377-413

98. The RAND Corporation (1963) the first fifteen years, Santa Monica, $\mathrm{Cal}$

99. van Laak D (2008) Planung. Geschichte und Gegenwart des Vorgriffs auf die Zukunft, In: Geschichte und Gesellschaft 34: 305-326

100. von Weizsäcker CF (1963) Bedingungen des Friedens. Rede zur Verleihung des Friedenspreises des Deutschen Buchhandels. In: von Weizsäcker CF (ed) (1994) Der bedrohte Friede - heute. Hanser, München, pp 125-137

101. von Weizsäcker CF (1965) Gedanken über die Zukunft des technischen Zeitalters. In: von Weizsäcker CF (ed) Gedanken über unsere Zukunft. Drei Reden. Vandenhoeck \& Ruprecht, Göttingen, pp 6-28

102. von Weizsäcker CF (1968) Über die Kunst der Prognose. Frankfurt

103. von Weizsäcker CF (1971) Einleitung. In: von Weizsäcker CF, Afheldt $\mathrm{H}$ (eds) Kriegsfolgen und Kriegsverhütung. Hanser, München, pp 3-21

104. Weingart P (1983) Verwissenschaftlichung der gesellschaftpolitisierung der wissenschaft. Z Soziol 12:225-241

105. Weingart P (2005) Die Wissenschaft der Öffentlichkeit und die Öffentlichkeit der Wissenschaft. In: Weingart P (ed) Die Wissenschaft der Öffentlichkeit. Essays zum Verhältnis von Wissenschaft, Medien und Öffentlichkeit. Velbrück Wissenschaft, Weilerswist, pp 9-33

106. Weiss C (1986) The many meanings of research utilization. In: Bulmer M (ed) Social science and social policy. Allen \& Unwin, London, pp 31-40

107. Wiener N (1948) Cybernetics or control and communication in the animal and the machine. The Technology Press, New York

108. Wiener N (1950) The human use of human beings: cybernetics and society. Houghton Mifflin, Boston

109. Wittner LS (1997) Resisting the bomb. a history of the world nuclear disarmament movement, 1954-1970. Stanford Univ. Press, Stanford

110. Zundel R (1967) Hofstaat oder Kanzlerstab? Erkenntnis aus der Wehrkrise. Kiesinger fehlt ein brauchbares Regierungsinstrument. In Die Zeit, 28th July 1967 